\title{
28 Resarch Square \\ Diminished Corticomotor Excitability in Gulf War I Veterans with Chronic Pain Symptoms
}

\author{
Karen Lei \\ Veterans Medical Research Foundation \\ Alphonsa Kunnel \\ VA San Diego Healthcare System \\ Valerie Metzger-Smith \\ VA San Diego Healthcare System \\ Shahrokh Golshan \\ Veterans Medical Research Foundation \\ Jennifer Javors \\ VA San Diego Healthcare System \\ Jennie Wei \\ VA San Diego Healthcare System \\ Roland Lee \\ VA San Diego Healthcare System \\ Michael Vaninetti \\ VA San Diego Healthcare System \\ Thomas Rutledge \\ VA San Diego Healthcare System \\ Albert Leung ( $\nabla$ ayleung@health.ucsd.edu ) \\ https://orcid.org/0000-0002-1614-5883
}

\section{Research article}

Keywords: Cortical excitability, chronic pain, Gulf War illness, transcranial magnetic stimulation, resting motor threshold

Posted Date: June 25th, 2020

DOI: https://doi.org/10.21203/rs.3.rs-37654/v1

License: (c) (i) This work is licensed under a Creative Commons Attribution 4.0 International License. Read Full License 


\section{Abstract}

Background: Diminished motor cortical excitability, as a measurement of increased resting motor threshold with transcranial magnetic stimulation (TMS), is known to be associated with chronic pain conditions. Over 175,000 veterans who were deployed to the Persian Gulf in 1990-91 suffer from an unexplained multisymptom illness termed Gulf War Illness (GWI) with chronic headaches and diffuse body pain as the most commonly reported symptoms. This study hypothesized that veterans with Gulf War Illness related pain exhibit diminished corticomotor excitability associated with chronic pain states and aimed to assess the resting motor threshold (RMT) at the primary motor cortex (M1) in veterans with GWI.

Methods: Single pulse TMS was administered over the left motor cortex, using anatomical scans of each subject to guide the TMS coil, starting at $25 \%$ of maximum stimulator output (MSO) and increasing in steps of $2 \%$ until a motor response with a $50 \mu \mathrm{V}$ peak to peak amplitude, defined as the RMT, was evoked at the flexor pollicis brevis muscle. RMT was then analyzed using Repeated Measures Analysis of Variance (RM-ANOVA).

Results: Gulf War Veterans (GWV) with chronic headaches and body pain $(\mathrm{N}=20)$ had a significantly $(\mathrm{P}<0.001)$ higher average resting motor threshold $(\% \pm \mathrm{SD})$ of $77.2 \% \pm 16.7 \%$ compared to age and gender matched GWV Controls $(\mathrm{N}=20)$, whose average was $55.6 \% \pm 8.8 \%$.

Conclusion: This study demonstrated that a higher level of stimulation was required to evoke a motor response in veterans with GWI related pain. This diminished corticomotor excitability that suggests a reduced state of supraspinal pain modulatory function. Though further studies will be needed, TMS may provide a means of effectively rectifying this modulatory deficit.

\section{Introduction}

Gulf War Illness (GWI) is a chronic multisymptom illness that uniquely affects military personnel of the 1990-91 Persian Gulf War. An estimated $25-32 \%$ of the 700,000 veterans returning from theater in the Persian Gulf have exhibited a sequela of symptoms characterized by GWI. These symptoms include neurological dysfunction, gastrointestinal, respiratory, or dermatological issues as well as pain and fatigue. $(1,2)$ Of those, headaches and diffuse body pain have been reported as two of the most debilitating conditions of Gulf War Illness. $(3,4)$ While the pathophysiology underlying pain symptomology has not been well defined, assessing the underlying cortical excitability can provide a new level of understanding in any associated aberrant central pain neuromodulatory functions, and thus potentially providing guidance for therapeutic intervention. While it is widely accepted that chronic pain states can be associated with impaired corticomotor excitability represented by a diminished supraspinal modulatory state from traumatic or non-traumatic causes.(5-10) To the authors' best knowledge, no study has been conducted to assess the corticomotor excitability in patients with GWI related chronic headache and pain problems.

Transcranial magnetic stimulation (TMS) can evoke action potentials on the cerebral cortex, and is one of the most established methods for assessing motor cortical excitability via the measurement of the resting motor threshold (RMT), defined as the minimum percentage of the maximum intensity needed to illicit a motor response demonstrated on an electromyogram.(11)

To further the understanding of the pathophysiology of pain associated with GWI, this study compared RMT in patients with GWI-associated chronic headaches, muscle, and joint pain, with gender and age matched Gulf War veterans who served in the same period, but did not exhibit these pain symptoms, hypothesizing that cortical excitability of the motor cortex is suppressed in patients with GWI. 


\section{Methods}

Veterans who served in the Persian Gulf War I between August 1990 and July 1991 were screened and enrolled based on the study protocol approved by the Institutional Human Subject Protection Committee. The study consisted of three visits as follows: 1) Informed Consent and Screening; 2) MRI Scan; and 3) Resting Motor Threshold Procedure with TMS. On average, study participants completed all three visits within two weeks.

\section{Screening and Demographics}

The main study inclusion criteria consisted of male or female veterans between the ages of 18 and 65 years old who served in the Persian Gulf for at least thirty consecutive days between August 1990 and July 1991. Veterans in the Gulf War Illness-associated headache and pain group (GWV-HAP) were also required to meet the following diagnostic criteria:

1. CDC Criteria for Gulf War Illness (at least 1 symptom in 2 of the following domains)(12)

Pain

Fatigue

Cognition and Mood

2. Kansas Criteria for Gulf War Illness (at least 3 out of the 6 following domains)(13)

Pain

Neurologic

Fatigue

GI Symptoms

Respiratory Symptoms

Skin Symptoms

3. International Headache Society Criteria (ICHD-3) for Migraine Headaches Without Aura(14)

At least 5 headache attacks, fulfilling the following criteria i and ii:

Headache attacks lasting 4-72 hours

Occupied by nausea and/or photophobia and phonophobia

In addition, GWV-HAP subjects were required to have an average headache exacerbation intensity greater than or equal to $3 / 10$ on a numerical rating scale (NRS), occurring at least three times a week and at least one of which should have lasted more than four hours in the past three months.(15) They were also required to have daily muscle pain with an intensity of greater than or equal to $3 / 10$ on a NRS and daily joint pain with an intensity of greater than or equal to $3 / 10$ on a NRS.(15)

Veterans who met the initial study criteria of a male or female veteran between 18 and 65 years old who served in the Persian Gulf for at least thirty consecutive days between August 1990 and July 1991, but did not meet both GWI diagnostic criteria and the pain conditions defined above for GWV-HAP were recruited for the GWV Control group. GWV Control group veterans were gender and age-matched within one year to a veteran in the GWV-HAP group.

Veterans were excluded from both GWV-HAP and GWV Control groups of the study if they had any of the following: pregnancy; history of pacemaker implant; any ferromagnetic material in the brain and/or body; history of dementia; major psychiatric diseases; life threatening diseases; presence of any chronic neuropathic pain; history of seizures; pending litigation; low back pain with mechanical origins; lack of ability to understand or speak English; history of 
traumatic brain injury; chronic tension or cluster headaches; or ongoing cognitive rehabilitation or treatment for PostTraumatic Stress Disorder (PTSD).

After subjects were enrolled into the study, demographic information pertaining to age, gender, race, body mass index (BMI), and Persian Gulf War durations and duties were collected. Those who served in the 1990-91 Persian Gulf War were indicated as serving under "Gulf War l," whereas those who served in both the 1990-91 Persian Gulf War and post1991 Gulf War were indicated as "Both." Time served in the Persian Gulf was reported in months. Military branches were reported as either Navy, Marines, Army, or Other, with "Other" consisting of the Coast Guard and Air Force branches. Combat status was reported based on military occupational specialty, with combat roles coded as " $\mathrm{C}$ " and non-combat roles coded as "NC."

\section{Neuroimaging Data Acquisition}

Neuroimaging data was acquired through magnetic resonance imaging (MRI) using a General Electric Discovery MR750 3.0T scanner. During the scan, subjects were instructed to keep the head still and padding was provided between the subject's head and the scanner head coil to minimize head movement. Anatomical scans were obtained with magnetization prepared rapid gradient echo (MP RAGE) samplings (176 slices, T1 450, TE 3.172, TR (ms) 8.132, $256 \times 256$ and $1 \mathrm{~mm}$ slice thickness).

\section{Study Procedure: Resting Motor Threshold}

\section{Preparation}

Subjects were asked to sit in a comfortable chair and relax as much as possible. Electromyography (EMG) recordings (Xltek, Oakville, Ontario, Canada) were collected through silver-silver chloride surface electrodes attached to the contralateral flexor pollicis brevis muscle and a $3 \mathrm{~cm}$ diameter ground electrode placed on the back of the hand. Manufacturer preinstalled software was used to collect signal with a recording time window of $200 \mathrm{~ms}$, gain of $100 \mathrm{uV}$, notch filter $60 \mathrm{~Hz}$, LFF $20 \mathrm{~Hz}$, and HFF $10 \mathrm{k} \mathrm{Hz}$. TMS was performed with a figure-of-eight Cool-B65 coil connected to MagPro R30 (Alpine BioMed, Fountain Valley, CA, USA).

\section{TMS Neuronavigation System}

All anatomical MRI images were processed using BrainVoyager TMS Neuronavigation Software (Brain Innovation, Maastricht, The Netherlands), here anatomical scans were oriented along the anterior commissure (AC) and posterior commissure (PC) plane. The transformed images were used to create 3D head and brain meshes, where head fiducial points (FDP) were marked. Utilizing the BrainVoyager ultrasound-based co-registration system via sensors attached to each subject's face and the TMS coil, stereotaxic data was used to determine the spatial position of the TMS stimulation site in relation to each subject. A digitizing pen with ultrasound sensors was used to mark each subject's face, which was co-registered to corresponding FDPs on a subject's head mesh. As a result, TMS coil was visualized in real time and space, allowing the investigator to focus the magnetic flux on a specific target region.

\section{Resting Motor Threshold}

Under the guidance of BrainVoyager Neuronavigation, a constant suprathreshold stimulus intensity was applied from the TMS coil on the left primary motor cortex (LMC) in an ascending order. Given the pain symptoms in this patient population are diffuse, the laterality of the testing side was chosen for the ease of operation and location derived from previous pain related studies. A single pulse TMS was delivered to the LMC starting at $25 \%$ of maximum stimulator output (MSO) and increasing in steps of $2 \%$ until a motor response at the flexor pollicis brevis muscle of $50 \mu \mathrm{V}$ peak to peak amplitude in five out of ten consecutive trials was evoked. The MSO of the MagPro R30 used in this procedure was $1850 \mathrm{~V}$, and the minimum stimulus required for the evoked response was defined as the resting motor threshold 
(RMT).(16) The cortical location for flexor pollicis brevis muscle was obtained by using the personalized brain mesh to trace the precentral gyrus region corresponding to the contralateral hand in the homunculus layout, which was confirmed using the EMG. Once the cortical location for the obtained RMT was marked, the distance between the center of the TMS coil to the target site was recorded.(17)

\section{Data Analysis}

The within subject design was used for this study. All GWV-HAP veterans were age and gender matched to a counterpart control group, and there was no significant difference between them on these measurements using ChiSquare for categorical data and Analysis of Variance for continuous data. Furthermore, these two groups were not significantly different on race, Gulf War period, duration, number of deployments, military branch, combat status, nor BMI. The primary outcome, resting motor threshold (RMT) data, was normally distributed and analyzed using Repeated Measures Analysis of Variance (RM-ANOVA) with one within-factor of headache and pain; GWV-HAP for those who met the headache and pain criteria, and GWV Control for those who did not meet the headache and pain criteria; using SPSS version 23.

\section{Results}

\section{Demographics}

Forty-seven veterans were screened based on the study protocol approved by the Institutional Human Subject Protection Committee. Out of the forty-seven veterans, one failed the study screening, five dropped prior to study procedures due to time commitment or MRI complications, and one was excluded due to information shared after the study procedures that would exclude him or her from the study. The remaining forty gender and age-matched veterans (20 GWV-HAP and 20 GWV Control) were enrolled in the study and their data analyzed.

On average, the age of veterans (years old $\pm S D)$ in the GWV-HAP $(N=20)$ group were $50.7 \pm 4.2$ years old, serving an average duration (months $\pm S D$ ) of $7.9 \pm 8.7$ months in the Persian Gulf over 1.6 \pm 1.2 (numbers $\pm S D$ ) of deployments (Table 1). The age of veterans (years old $\pm S D)$ in the GWV Control group $(N=20)$ were $50.8 \pm 4.2$ years old and served $8.2 \pm 3.8$ months in the Persian Gulf with $1.3 \pm 0.6$ number of deployments (Table 2). All subjects were male in both groups. Five veterans in the GWV-HAP group served in both Gulf War I and post-1991 Gulf War periods, whereas four in the GWV Control group served in both wars. The remaining veterans served in only Gulf War I. The GWV- HAP group consisted of twelve Caucasians, three Asians, two African-Americans, two Hispanics, and one Pacific Islander, whereas the GWV Control group consisted of eleven Caucasians, five African-Americans, two Hispanics, one Pacific Islander, and one African-American/Asian. In the GWV-HAP group, nine veterans were in the Navy branches, seven in the Marines, three in the Army, and one in Other, compared to ten Navy, six Marine, and four Army subjects in the GWV Control group. Eight subjects in the GWV-HAP group were in Combat (C) roles, compared to three subjects in the GWV Control group. The remaining subjects were Non-Combat (NC). Body Mass Index (BMI $\pm S D$ ) in the GWV-HAP group was higher at $30.3 \pm 4.0$ compared to the GWV Control group who had an average BMI of $29.8 \pm 4.0$. BMI data was missing from one subject in the GWV Control group, who was excluded from the calculation of its average. 
Table 1

GWV-HAP Group Demographics

\begin{tabular}{|c|c|c|c|c|c|c|c|c|c|}
\hline Subject & Gender & Age & Race & $\begin{array}{l}\text { Gulf } \\
\text { War } \\
\text { Period }\end{array}$ & $\begin{array}{l}\text { Duration in } \\
\text { Gulf } \\
\text { (months) }\end{array}$ & $\begin{array}{l}\text { \# of } \\
\text { Deployments }\end{array}$ & $\begin{array}{l}\text { Military } \\
\text { Branch }\end{array}$ & $\begin{array}{l}\text { Combat } \\
\text { Status } \\
\text { (C/NC) }\end{array}$ & BMI \\
\hline 1 & $M$ & 45 & $\begin{array}{l}\text { African } \\
\text { American }\end{array}$ & Both & 13 & 3 & Navy & $\mathrm{NC}$ & 25.9 \\
\hline 2 & $M$ & 46 & $\begin{array}{l}\text { Pacific } \\
\text { Islander }\end{array}$ & $\begin{array}{l}\text { Gulf } \\
\text { War I }\end{array}$ & 2 & 1 & Navy & $\mathrm{NC}$ & 35.6 \\
\hline 3 & $M$ & 46 & Caucasian & $\begin{array}{l}\text { Gulf } \\
\text { War I }\end{array}$ & 6 & 1 & Navy & NC & 28.8 \\
\hline 4 & $M$ & 47 & Caucasian & $\begin{array}{l}\text { Gulf } \\
\text { War I }\end{array}$ & 6 & 1 & Marines & C & 29.2 \\
\hline 5 & $M$ & 47 & $\begin{array}{l}\text { African } \\
\text { American }\end{array}$ & Both & 39 & 6 & Marines & C & 28.5 \\
\hline 6 & $\mathrm{M}$ & 47 & Hispanic & Both & 16 & 2 & Navy & $\mathrm{NC}$ & 31.5 \\
\hline 7 & $M$ & 48 & Caucasian & $\begin{array}{l}\text { Gulf } \\
\text { War I }\end{array}$ & 3 & 1 & Other & $\mathrm{NC}$ & 31.7 \\
\hline 8 & $M$ & 48 & Caucasian & $\begin{array}{l}\text { Gulf } \\
\text { War I }\end{array}$ & 5 & 1 & Navy & $\mathrm{NC}$ & 30.2 \\
\hline 9 & $M$ & 49 & Caucasian & $\begin{array}{l}\text { Gulf } \\
\text { War I }\end{array}$ & 6 & 1 & Marines & $\mathrm{NC}$ & 31.4 \\
\hline 10 & $M$ & 49 & Caucasian & $\begin{array}{l}\text { Gulf } \\
\text { War I }\end{array}$ & 10 & 1 & Marines & C & 30.0 \\
\hline 11 & $M$ & 50 & Caucasian & $\begin{array}{l}\text { Gulf } \\
\text { War I }\end{array}$ & 2 & 2 & Navy & C & 23.0 \\
\hline 12 & $M$ & 51 & Caucasian & $\begin{array}{l}\text { Gulf } \\
\text { War I }\end{array}$ & 3 & 1 & Marines & C & 28.0 \\
\hline 13 & $M$ & 51 & Caucasian & $\begin{array}{l}\text { Gulf } \\
\text { War I }\end{array}$ & 3 & 1 & Marines & $\mathrm{NC}$ & 32.2 \\
\hline 14 & $M$ & 53 & Hispanic & $\begin{array}{l}\text { Gulf } \\
\text { War I }\end{array}$ & 8 & 1 & Army & C & 31.6 \\
\hline 15 & $M$ & 53 & Caucasian & $\begin{array}{l}\text { Gulf } \\
\text { War I }\end{array}$ & 4 & 1 & Marines & C & 34.9 \\
\hline 16 & $M$ & 55 & Asian & $\begin{array}{l}\text { Gulf } \\
\text { War I }\end{array}$ & 3 & 1 & Army & C & 32.4 \\
\hline 17 & $M$ & 55 & Asian & $\begin{array}{l}\text { Gulf } \\
\text { War I }\end{array}$ & 4 & 1 & Navy & $\mathrm{NC}$ & 23.5 \\
\hline 18 & $M$ & 56 & Caucasian & Both & 6 & 2 & Navy & $\mathrm{NC}$ & 40.1 \\
\hline 19 & $M$ & 57 & Caucasian & Both & 16 & 2 & Navy & $\mathrm{NC}$ & 27.1 \\
\hline 20 & $M$ & 60 & Asian & $\begin{array}{l}\text { Gulf } \\
\text { War I }\end{array}$ & 6 & 1 & Army & $\mathrm{NC}$ & 30.3 \\
\hline
\end{tabular}




\begin{tabular}{|c|c|c|c|c|c|c|c|}
\hline Subject & Age Race & $\begin{array}{l}\text { Gulf } \\
\text { War } \\
\text { Period }\end{array}$ & $\begin{array}{l}\text { Duration in } \\
\text { Gulf } \\
\text { (months) }\end{array}$ & $\begin{array}{l}\text { \# of } \\
\text { Deployments }\end{array}$ & $\begin{array}{l}\text { Military } \\
\text { Branch }\end{array}$ & $\begin{array}{l}\text { Combat } \\
\text { Status } \\
\text { (C/NC) }\end{array}$ & BMI \\
\hline $\begin{array}{l}\text { Average } \pm S D \\
(N=20)\end{array}$ & $50.7 \pm 4.2$ & & $7.9 \pm 8.7$ & $1.6 \pm 1.2$ & & & $\begin{array}{r}30.3 \\
\pm 4.0\end{array}$ \\
\hline
\end{tabular}


Table 2

GWV Control Group Demographics

\begin{tabular}{|c|c|c|c|c|c|c|c|c|c|}
\hline Subject & Gender & Age & Race & $\begin{array}{l}\text { Gulf } \\
\text { War } \\
\text { Period }\end{array}$ & $\begin{array}{l}\text { Duration } \\
\text { in Gulf } \\
\text { (months) }\end{array}$ & $\begin{array}{l}\text { \# of } \\
\text { Deployments }\end{array}$ & $\begin{array}{l}\text { Military } \\
\text { Branch }\end{array}$ & $\begin{array}{l}\text { Combat } \\
\text { Status } \\
\text { (C/NC) }\end{array}$ & BMI \\
\hline 21 & M & 46 & Hispanic & $\begin{array}{l}\text { Gulf } \\
\text { War I }\end{array}$ & 4 & 1 & Marines & $\mathrm{NC}$ & 26.2 \\
\hline 22 & $M$ & 46 & Caucasian & $\begin{array}{l}\text { Gulf } \\
\text { War I }\end{array}$ & 8 & 1 & Army & $\mathrm{NC}$ & 26.0 \\
\hline 23 & M & 46 & Caucasian & $\begin{array}{l}\text { Gulf } \\
\text { War I }\end{array}$ & 6 & 1 & Marines & C & 29.8 \\
\hline 24 & $M$ & 47 & Caucasian & Both & 17 & 2 & Marines & C & 30.0 \\
\hline 25 & $M$ & 47 & $\begin{array}{l}\text { African } \\
\text { American }\end{array}$ & $\begin{array}{l}\text { Gulf } \\
\text { War I }\end{array}$ & 6.5 & 1 & Navy & $\mathrm{NC}$ & 35.6 \\
\hline 26 & $M$ & 48 & $\begin{array}{l}\text { African } \\
\text { American }\end{array}$ & $\begin{array}{l}\text { Gulf } \\
\text { War I }\end{array}$ & 3 & 1 & Navy & $\mathrm{NC}$ & 37.0 \\
\hline 27 & $M$ & 48 & Caucasian & $\begin{array}{l}\text { Gulf } \\
\text { War I }\end{array}$ & 3 & 1 & Marines & $\mathrm{NC}$ & 37.3 \\
\hline 28 & M & 48 & Hispanic & $\begin{array}{l}\text { Gulf } \\
\text { War I }\end{array}$ & 6 & 1 & Army & $\mathrm{NC}$ & - \\
\hline 29 & $M$ & 49 & $\begin{array}{l}\text { African } \\
\text { American/Asian }\end{array}$ & $\begin{array}{l}\text { Gulf } \\
\text { War I }\end{array}$ & 6 & 1 & Marines & C & 30.5 \\
\hline 30 & $M$ & 49 & $\begin{array}{l}\text { African } \\
\text { American }\end{array}$ & $\begin{array}{l}\text { Gulf } \\
\text { War I }\end{array}$ & 6 & 1 & Navy & $\mathrm{NC}$ & 29.7 \\
\hline 31 & M & 49 & Pacific Islander & Both & 8 & 2 & Navy & $\mathrm{NC}$ & 27.9 \\
\hline 32 & $M$ & 51 & Caucasian & Both & 15 & 2 & Navy & $\mathrm{NC}$ & 29.0 \\
\hline 33 & $M$ & 51 & Caucasian & $\begin{array}{l}\text { Gulf } \\
\text { War I }\end{array}$ & 10 & 1 & Navy & $\mathrm{NC}$ & 26.3 \\
\hline 34 & $M$ & 53 & Caucasian & $\begin{array}{l}\text { Gulf } \\
\text { Warl }\end{array}$ & 9 & 1 & Army & $\mathrm{NC}$ & 25.8 \\
\hline 35 & M & 54 & Caucasian & $\begin{array}{l}\text { Gulf } \\
\text { War I }\end{array}$ & 5 & 1 & Navy & $\mathrm{NC}$ & 25.4 \\
\hline 36 & $M$ & 55 & Caucasian & $\begin{array}{l}\text { Gulf } \\
\text { War I }\end{array}$ & 11 & 1 & Marines & $\mathrm{NC}$ & 27.2 \\
\hline 37 & $M$ & 56 & $\begin{array}{l}\text { African } \\
\text { American }\end{array}$ & Both & 12 & 3 & Navy & $\mathrm{NC}$ & 28.3 \\
\hline 38 & $M$ & 56 & Caucasian & $\begin{array}{l}\text { Gulf } \\
\text { War I }\end{array}$ & 6 & 1 & Navy & $\mathrm{NC}$ & 34.0 \\
\hline 39 & $M$ & 58 & Caucasian & $\begin{array}{l}\text { Gulf } \\
\text { War I }\end{array}$ & 11 & 1 & Army & $\mathrm{NC}$ & 34.4 \\
\hline 40 & $M$ & 59 & $\begin{array}{l}\text { African } \\
\text { American }\end{array}$ & $\begin{array}{l}\text { Gulf } \\
\text { War I }\end{array}$ & 12 & 1 & Navy & $\mathrm{NC}$ & 25.7 \\
\hline
\end{tabular}




\begin{tabular}{|c|c|c|c|c|c|c|c|c|c|}
\hline Subject & Gender & Age & Race & $\begin{array}{l}\text { Gulf } \\
\text { War } \\
\text { Period }\end{array}$ & $\begin{array}{l}\text { Duration } \\
\text { in Gulf } \\
\text { (months) }\end{array}$ & $\begin{array}{l}\text { \# of } \\
\text { Deployments }\end{array}$ & $\begin{array}{l}\text { Military } \\
\text { Branch }\end{array}$ & $\begin{array}{l}\text { Combat } \\
\text { Status } \\
\text { (C/NC) }\end{array}$ & BMI \\
\hline $\begin{array}{l}\text { Average } \pm \\
(\mathrm{N}=20)\end{array}$ & & \multicolumn{2}{|c|}{$50.8 \pm 4.2$} & & $8.2 \pm 3.8$ & $1.3 \pm 0.6$ & & & $\begin{array}{l}29.8 \\
\pm 4.0\end{array}$ \\
\hline
\end{tabular}

There were no significant differences found between groups in all aforementioned demographic categories (see Table 3). 
Table 3

Between Group Differences

\begin{tabular}{|c|c|c|c|c|c|c|}
\hline \multirow[b]{2}{*}{ Gender } & \multirow{2}{*}{$\begin{array}{l}\text { Values } \\
\mathrm{N}(\%)\end{array}$} & \multicolumn{2}{|c|}{ GWV-HAP } & \multicolumn{2}{|c|}{ GWV-Control } & \multirow{4}{*}{$\begin{array}{l}\text { P-value } \\
1.000\end{array}$} \\
\hline & & & & & & \\
\hline Male & & 20 & $(100 \%)$ & 20 & $(100 \%)$ & \\
\hline Female & & 0 & $(0 \%)$ & 0 & $(0 \%)$ & \\
\hline Age & $\operatorname{Avg} \pm S D$ & 50.7 & \pm 4.2 & 50.8 & \pm 4.2 & 0.911 \\
\hline Race & $\mathrm{N}(\%)$ & & & & & 0.675 \\
\hline Caucasian & & 12 & $(60 \%)$ & 11 & $(55 \%)$ & \\
\hline African American & & 2 & $(10 \%)$ & 5 & $(25 \%)$ & \\
\hline Hispanic & & 2 & $(10 \%)$ & 2 & $(10 \%)$ & \\
\hline Pacific Islander & & 1 & $(5 \%)$ & 1 & $(5 \%)$ & \\
\hline Asian & & 3 & $(15 \%)$ & 0 & $(0 \%)$ & \\
\hline Other & & 0 & $(0 \%)$ & 1 & $(5 \%)$ & \\
\hline Gulf War Period & $N(\%)$ & & & & & 0.705 \\
\hline Gulf War I & & 15 & $(75 \%)$ & 16 & $(80 \%)$ & \\
\hline Both & & 5 & $(25 \%)$ & 4 & $(20 \%)$ & \\
\hline Duration in Gulf (months) & $A v g \pm S D$ & 7.9 & \pm 8.7 & 8.2 & \pm 3.8 & 0.933 \\
\hline \# of Deployments & $A v g \pm S D$ & 1.6 & \pm 1.2 & 1.3 & \pm 0.6 & 0.313 \\
\hline Military Branch & $N(\%)$ & & & & & 0.736 \\
\hline Navy & & 9 & $(45 \%)$ & 10 & $(50 \%)$ & \\
\hline Marines & & 7 & $(35 \%)$ & 6 & $(30 \%)$ & \\
\hline Army & & 3 & $(15 \%)$ & 4 & $(20 \%)$ & \\
\hline Other & & 1 & $(5 \%)$ & 0 & $(0 \%)$ & \\
\hline Combat Status & $N(\%)$ & & & & & 0.077 \\
\hline Combat & & 8 & $(40 \%)$ & 3 & $(15 \%)$ & \\
\hline Non-Combat & & 12 & $(60 \%)$ & 17 & $(85 \%)$ & \\
\hline BMI & $A v g \pm S D$ & 30.3 & \pm 4.0 & 29.8 & \pm 4.0 & 0.695 \\
\hline
\end{tabular}

Resting Motor Threshold

GWV-HAP subjects required a significantly higher level of stimulation needed to evoke a motor response with the average RMT $(\% \pm S D)$ of $77.2 \% \pm 16.7 \%$ compared to GWV Control subjects whose average RMT(\% \pm SD) was $55.6 \%$ $\pm 8.8 \%\left(f_{1,19}=24.24, p<0.001\right.$; Fig. 1$)$. 


\section{Discussion}

Supraspinal pain perception consists of mainly three functional regions: 1) sensory discriminatory regions such as the primary and secondary somatosensory cortices (SSC1 and SSC2) and inferior parietal lobe (IPL); 2) affective regions such as anterior cingulate cortex (ACC) and insula (IN); and 3) modulatory regions involving motor and various regions of prefrontal cortices (PFCs). $(18,19)$ Additionally, the insula (IN) has been known to play a role in assessing the magnitude of pain, while the inferior parietal lobe (IPL) aids in distinguishing spatial discrimination in pain perception. (20-23) Chronic pain state is often associated with a mal-adaptation in the supraspinal pain processing, which is often accompanied with diminished modulatory functional connectivity from the prefrontal cortices with diminished motor cortex excitability as reflected by an elevated resting motor threshold. $(24,25)$

Persian Gulf War veterans in this study demonstrated an increase in RMT level compared to their non-pain Gulf War veteran counterparts. The need for a higher level of stimulation in Gulf War veterans is consistent with other chronic pain conditions resulted from either direct or indirect neuronal traumas which resulted in impaired supraspinal pain modulation(26-34). Although the pathophysiology behind the headaches and diffuse body pain in this population has not been explicitly defined, the observed functional deficit in supraspinal cortical modulatory function serves as a significant step in understanding the pathophysiology underlying the high prevalence of chronic pain states in this patient population.(35-37)

While transcranial magnetic stimulation-evoked resting motor threshold has been demonstrated to be a reliable method for assessing cortical excitability, it may also be a viable solution for the chronic pain experienced by these veterans. TMS is approved by the United States Food and Drug Administration for treating depression and migraine headaches.(38-40) In addition, multiple meta-analyses and panel consensus review definitively supported a high level of evidence for treating central neuropathic states, such as in the management of chronic and debilitating headaches in mild Traumatic Brain Injury patients. $(17,41)$ High frequency $(>1 \mathrm{~Hz})$ TMS works by evoking action potentials to directly excite the motor cortex and potentially regain cortical excitability, which cannot be accomplished with traditional pharmacological methods. Since Gulf War veterans with Gulf War Illness-associated headaches and pain present with a similarly increased RMT profile, it is possible they may also find relief with repetitive transcranial magnetic stimulation in the form of increased pain modulatory function.

Limitations to the study include those due to an all-male study population and recruitment from a single site. Although all subjects were successfully gender and age-matched to a counterpart in the other group of the study, all forty veterans were male which is not indicative of the true veteran population that was deployed to the Persian Gulf in 1990-91. While female veterans were screened for the study, they were far fewer in number compared to male veterans who met the criteria. This is most likely explained by the inherently male-dominated target population of $1990-91 \mathrm{Gulf}$ War veterans, of which only $7 \%$ of the total deployed personnel consisted of females.(42) Furthermore, 70-78\% of female veterans report pain symptoms, meaning only a small number of female veterans would meet the Control criteria while also living near the recruitment site. $(43,44)$ Other reasons that may have led to this all-male result include the current distribution of female to male veterans at Veteran Affairs San Diego Healthcare System. Since veterans with pain required a gender and age matched healthy counterpart, it became less likely that a female was included in the study. Additionally, recruitment occurred primarily in San Diego County, which is heavily dominated by Naval and Marine bases. Future studies would benefit from recruitment from multiple sites as it would provide a study population that is more representative of the 1990-91 Persian Gulf War veterans in terms of military branches and gender.

In short, the observed result from the current study suggests that the high prevalence of headaches and diffuse body pain in 1990-91 Persian Gulf War veterans is associated with impaired cortical excitability and pain modulation. This was expressed by a higher resting motor threshold in GWV-HAP veterans compared to control. The significance of 
transcranial magnetic stimulation in this study is two-fold. TMS was utilized as the primary modality in assessing resting motor threshold. In a clinical setting, the same TMS machine may also provide veterans potential benefit longterm pain relief that is currently lacking in the management of this multisymptom illness.

\section{Abbreviations}

transcranial magnetic stimulation

TMS; Gulf War Illness:GWl; resting motor threshold:RMT; primary motor cortex:M1; maximum stimulator output:MSO; Gulf War Veterans:GWV; Veterans in the Gulf War IIIness-associated headache and pain group:GWV-HAP; International Headache Society Criteria:ICHD-3; numerical rating scale:NRS; Post-Traumatic Stress Disorder:PTSD; body mass index:BMI; Combat:C; Non-Combat:NC; magnetic resonance imaging:MRl; magnetization prepared rapid gradient echo:MP RAGE; Electromyography:EMG; anterior commissure:AC; posterior commissure:PC; head fiducial points:FDP; left primary motor cortex:LMC; Repeated Measures Analysis of Variance:RM-ANOVA; primary somatosensory cortices:SSC1; secondary somatosensory cortices:SSC2; prefrontal cortices:PFCs; insula:IN; inferior parietal lobe:IPL

\section{Declarations}

\section{Ethics approval and consent to participate}

All research subjects provided informed consent for the study. The research protocol was approved by the Veteran's Affairs San Diego Healthcare System Institutional Review Board for Human Research Protection.

\section{Consent for publication}

Written informed consent for publication of clinical details was obtained from the patients.

\section{Availability of data and materials}

The data used and/or analyzed in this study are available from the corresponding author on reasonable request.

\section{Competing interests}

The authors declare that they have no competing interests.

\section{Funding}

This study received funding support from the following agency: Department of Defense Congressionally Directed Medical Research Program Grant (W81XWH-16-1-0754).

\section{Authors' contributions}

$\mathrm{KL}, \mathrm{AK}$, and VMS assisted in conducting the study, data analysis, and manuscript preparation. SG assisted in the study design, data analysis, and manuscript preparation. JJ and JW assisted in patient evaluation, recruitment, and screening. RL assisted in neuroimaging assessment. MV assisted in conducting the study and patient evaluation. TR assisted in patient evaluation. AL designed and conducted the study and assisted in manuscript preparation. 


\section{Acknowledgements}

Not Applicable

\section{References}

1. White RF, Steele L, O'Callaghan JP, Sullivan K, Binns JH, Golomb BA et al (2016) Recent research on Gulf War illness and other health problems in veterans of the 1991 Gulf War: Effects of toxicant exposures during deployment. Cortex 74:449-475

2. Steele L, Sastre A, Gerkovich MM, Cook MR (2012) Complex factors in the etiology of Gulf War illness: wartime exposures and risk factors in veteran subgroups. Environ Health Perspect 120(1):112-118

3. Rayhan RU, Ravindran MK, Baraniuk JN (2013) Migraine in gulf war illness and chronic fatigue syndrome: prevalence, potential mechanisms, and evaluation. Front Physiol 4:181

4. Kuzma JM, Black DW (2006) Chronic widespread pain and psychiatric disorders in veterans of the first Gulf War. Curr Pain Headache Rep 10(2):85-89

5. Galhardoni R, Ciampi de Andrade D, Puerta MY, Brunoni AR, Varotto BL, de Siqueira JT et al (2019) Altered cortical excitability in persistent idiopathic facial pain. Cephalalgia 39(2):219-228

6. Schabrun SM, Burns E, Thapa T, Hodges P (2018) The Response of the Primary Motor Cortex to Neuromodulation is Altered in Chronic Low Back Pain: A Preliminary Study. Pain Med 19(6):1227-1236

7. Thibaut A, Zeng D, Caumo W, Liu J, Fregni F (2017) Corticospinal excitability as a biomarker of myofascial pain syndrome. Pain Rep 2(3):e594

8. Bushnell MC, Ceko M, Low LA (2013) Cognitive and emotional control of pain and its disruption in chronic pain. Nat Rev Neurosci 14(7):502-511

9. Leung A, Shukla S, Yang E, Canlas B, Kadokana M, Heald J et al. Diminished supraspinal pain modulation in patients with mild traumatic brain injury. Mol Pain. 2016;12

10. Parker RS, Lewis GN, Rice DA, McNair PJ (2016) Is Motor Cortical Excitability Altered in People with Chronic Pain? A Systematic Review and Meta-Analysis. Brain Stimul 9(4):488-500

11. Badawy RA, Loetscher T, Macdonell RA, Brodtmann A (2012) Cortical excitability and neurology: insights into the pathophysiology. Funct Neurol 27(3):131-145

12. Fukuda K, Nisenbaum R, Stewart G, Thompson WW, Robin L, Washko RM et al (1998) Chronic multisymptom illness affecting Air Force veterans of the Gulf War. JAMA 280(11):981-988

13. Steele L (2000) Prevalence and patterns of Gulf War illness in Kansas veterans: association of symptoms with characteristics of person, place, and time of military service. Am J Epidemiol 152(10):992-1002

14. Headache Classification Committee of the International Headache Society (IHS) The International Classification of Headache Disorders, 3rd edition. Cephalalgia. 2018;38(1):1-211

15. Williamson A, Hoggart B (2005) Pain: a review of three commonly used pain rating scales. J Clin Nurs 14(7):798804

16. Khedr EM, Kotb H, Kamel NF, Ahmed MA, Sadek R, Rothwell JC (2005) Longlasting antalgic effects of daily sessions of repetitive transcranial magnetic stimulation in central and peripheral neuropathic pain. J Neurol Neurosurg Psychiatry 76(6):833-838

17. Leung A, Shukla S, Fallah A, Song D, Lin L, Golshan S et al (2016) Repetitive Transcranial Magnetic Stimulation in Managing Mild Traumatic Brain Injury-Related Headaches. Neuromodulation 19(2):133-141

Page $13 / 15$ 
18. Apkarian AV, Bushnell MC, Treede RD, Zubieta JK (2005) Human brain mechanisms of pain perception and regulation in health and disease. Eur J Pain 9(4):463-484

19. Tracey I (2005) Nociceptive processing in the human brain. Curr Opin Neurobiol 15(4):478-487

20. Neugebauer V, Galhardo V, Maione S, Mackey SC (2009) Forebrain pain mechanisms. Brain Res Rev 60(1):226242

21. Tracey I (2007) Neuroimaging of pain mechanisms. Curr Opin Support Palliat Care 1(2):109-116

22. Seifert F, Fuchs O, Nickel FT, Garcia M, Dorfler A, Schaller G et al (2010) A functional magnetic resonance imaging navigated repetitive transcranial magnetic stimulation study of the posterior parietal cortex in normal pain and hyperalgesia. Neuroscience 170(2):670-677

23. Moulton EA, Pendse G, Becerra LR, Borsook D (2012) BOLD responses in somatosensory cortices better reflect heat sensation than pain. J Neurosci 32(17):6024-6031

24. Castillo Saavedra L, Mendonca M, Fregni F (2014) Role of the primary motor cortex in the maintenance and treatment of pain in fibromyalgia. Med Hypotheses 83(3):332-336

25. Mhalla A, de Andrade DC, Baudic S, Perrot S, Bouhassira D (2010) Alteration of cortical excitability in patients with fibromyalgia. Pain 149(3):495-500

26. Caeyenberghs K, Siugzdaite R, Drijkoningen D, Marinazzo D, Swinnen SP (2015) Functional Connectivity Density and Balance in Young Patients with Traumatic Axonal Injury. Brain Connect 5(7):423-432

27. Levin HS, Wilde EA, Hanten G, Li X, Chu ZD, Vasquez AC et al (2011) Mental state attributions and diffusion tensor imaging after traumatic brain injury in children. Dev Neuropsychol 36(3):273-287

28. Ljubisavljevic M, Milanovic S, Radovanovic S, Vukcevic I, Kostic V, Anastasijevic R (1996) Central changes in muscle fatigue during sustained submaximal isometric voluntary contraction as revealed by transcranial magnetic stimulation. Electroencephalogr Clin Neurophysiol 101(4):281-288

29. Pal D, Gupta RK, Agarwal S, Yadav A, Ojha BK, Awasthi A et al (2012) Diffusion tensor tractography indices in patients with frontal lobe injury and its correlation with neuropsychological tests. Clin Neurol Neurosurg 114(6):564-571

30. Palacios EM, Fernandez-Espejo D, Junque C, Sanchez-Carrion R, Roig T, Tormos JM et al (2011) Diffusion tensor imaging differences relate to memory deficits in diffuse traumatic brain injury. BMC Neurol 11:24

31. Tallus J, Lioumis P, Hamalainen H, Kahkonen S, Tenovuo O (2012) Long-lasting TMS motor threshold elevation in mild traumatic brain injury. Acta Neurol Scand 126(3):178-182

32. Tallus J, Lioumis P, Hamalainen H, Kahkonen S, Tenovuo O (2013) Transcranial magnetic stimulationelectroencephalography responses in recovered and symptomatic mild traumatic brain injury. J Neurotrauma 30(14):1270-1277

33. Bernabeu M, Demirtas-Tatlidede A, Opisso E, Lopez R, Tormos JM, Pascual-Leone A (2009) Abnormal corticospinal excitability in traumatic diffuse axonal brain injury. J Neurotrauma 26(12):2185-2193

34. Ah Sen CB, Fassett HJ, El-Sayes J, Turco CV, Hameer MM, Nelson AJ (2017) Active and resting motor threshold are efficiently obtained with adaptive threshold hunting. PLoS One 12(10):e0186007

35. Amourette C, Lamproglou I, Barbier L, Fauquette W, Zoppe A, Viret R et al (2009) Gulf War illness: Effects of repeated stress and pyridostigmine treatment on blood-brain barrier permeability and cholinesterase activity in rat brain. Behav Brain Res 203(2):207-214

36. Ferguson E, Cassaday HJ (2001) Theoretical accounts of Gulf War Syndrome: from environmental toxins to psychoneuroimmunology and neurodegeneration. Behav Neurol 13(3-4):133-147

Page 14/15 
37. Lewine JD, Davis JT, Bigler ED, Thoma R, Hill D, Funke M et al (2007) Objective documentation of traumatic brain injury subsequent to mild head trauma: multimodal brain imaging with MEG, SPECT, and MRI. J Head Trauma Rehabil 22(3):141-155

38. George MS, Taylor JJ, Short EB (2013) The expanding evidence base for rTMS treatment of depression. Curr Opin Psychiatry 26(1):13-18

39. Lipton RB, Pearlman SH (2010) Transcranial magnetic simulation in the treatment of migraine. Neurotherapeutics 7(2):204-212

40. Lefaucheur JP, Andre-Obadia N, Antal A, Ayache SS, Baeken C, Benninger DH et al (2014) Evidence-based guidelines on the therapeutic use of repetitive transcranial magnetic stimulation (rTMS). Clin Neurophysiol 125(11):2150-2206

41. Leung A, Fallah A, Shukla S, Lin L, Tsia A, Song D et al (2016) rTMS in Alleviating Mild TBI Related Headaches-A Case Series. Pain Physician 19(2):E347-E354

42. Coughlin SS, Krengel M, Sullivan K, Pierce PF, Heboyan V, Wilson LCC. A Review of Epidemiologic Studies of the Health of Gulf War Women Veterans. J Environ Health Sci. 2017;3(2)

43. Nahin RL (2017) Severe Pain in Veterans: The Effect of Age and Sex, and Comparisons With the General Population. J Pain 18(3):247-254

44. Haskell SG, Heapy A, Reid MC, Papas RK, Kerns RD (2006) The prevalence and age-related characteristics of pain in a sample of women veterans receiving primary care. J Womens Health (Larchmt) 15(7):862-869

\section{Figures}

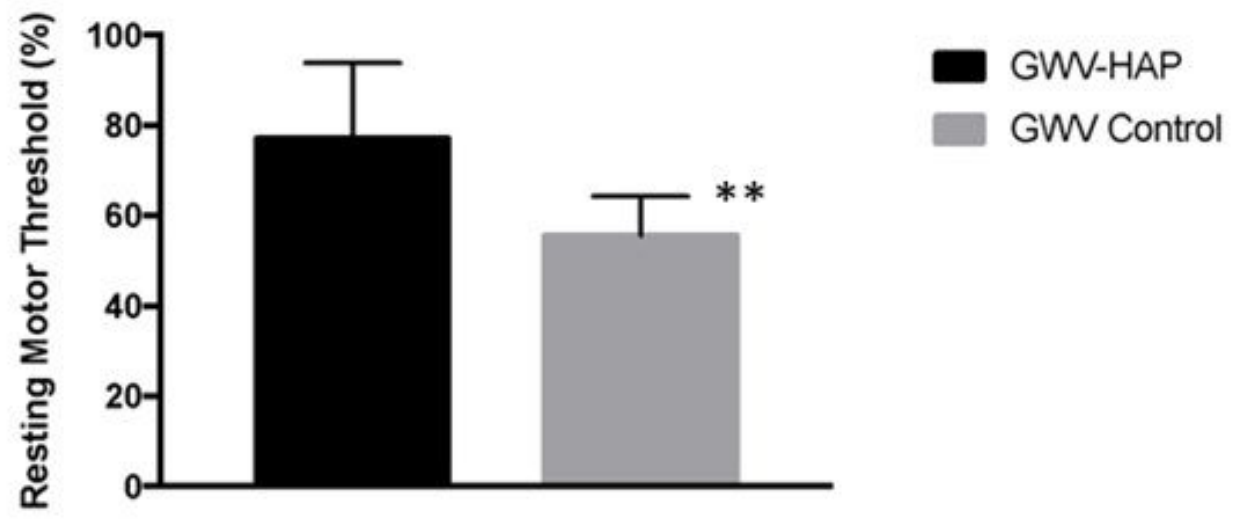

Figure 1

Average Resting Motor Threshold Determined via Transcranial Magnetic Stimulation (TMS). Resting motor threshold was determined using electromyograph recordings on the contralateral flexor pollicis brevis muscle with the TMS coil positioned over the primary motor cortex (M1). ${ }^{* *} \mathrm{p}<0.001$. 